\title{
Weather Vagaries and Fruit Growers Willingness to Pay for Fruit Crop Insurance in Kashmir Valley: An Exploratory Study
}

\author{
Arshad Bhat ${ }^{1, *}$, S. A. Wani ${ }^{1}$, Abid Sultan ${ }^{2}$, Showkat A. Itoo ${ }^{3}$, M. A. Kachroo ${ }^{2}$, Abid Qadir ${ }^{4}$, Aamir \\ Qureshi $^{5}$ \\ ${ }^{1}$ Rajiv Gandhi Chair in Contemporary Studies on Livelihood and Food Security, Sher-e-Kashmir University of Agricultural \\ Sciences and Technology of Kashmir, Shalimar Srinagar, India. \\ ${ }^{2}$ School of Agricultural Economics and Horti-Business Management, Sher-e-Kashmir University of Agricultural Sciences and \\ Technology of Kashmir, Shalimar Srinagar, India. \\ ${ }^{3}$ Centre of Central Asian Studies, University of Kashmir, Hazratbal Srinagar, India. \\ ${ }^{4}$ Department of Environmental Studies, The Glocal University, U.P., India. \\ ${ }^{5}$ Department of Management Studies, University of Kashmir, Hazratbal Srinagar, India.
}

How to cite this paper: Arshad Bhat, S. A. Wani, Abid Sultan, Showkat A. Itoo, M. A. Kachroo, Abid Qadir, Aamir Qureshi. (2021) Weather Vagaries and Fruit Growers Willingness to Pay for Fruit Crop Insurance in Kashmir Valley: An Exploratory Study. International Journal of Food Science and Agriculture, 5(3), 524-529. DOI: $10.26855 /$ ijfsa.2021.09.024

Received: July 18, 2021

Accepted: August 12, 2021

Published: September 8, 2021

*Corresponding author: Arshad Bhat, Rajiv Gandhi Chair in Contemporary Studies on Livelihood and Food Security, Sher-e-Kashmir University of Agricultural Sciences and Technology of Kashmir, Shalimar Srinagar, India. Email: bhatarshad09@gmail.com

\begin{abstract}
Pradhan Mantri Fasal Bima Yojana, a crop protection scheme along with the government of Jammu and Kashmir was launched to save the farmers/fruit growers from the unexpected events occurring due to bad weather on subsidised rates. The study was conducted to know the approach and behaviour of fruits growers regarding the insurance scheme and the amount they are willing/ready to pay for saving the crop/fruit against such untoward events. Contingent valuation through willingness to pay method was used to assess the impact of such scheme in a dominant fruit growing area district Shopian of Kashmir valley where most fruit cultivation is irrigation based. Present study was carried out on a sample of 400 fruit growers from 8 community blocks consisting of 8 villages and 50 samples from each village. The results of the study revealed that fruit growers are willing to pay Rs. 309 per kanal of land as premium to save the fruit from damages.
\end{abstract}

\section{Keywords}

Fruit Crop Insurance, Ill-weather, Willingness to Pay, Contingent Valuation Method, Government Schemes

\section{Introduction}

Farmers have faced income variability in almost every production season. Problems associated with dependence on rain fed agriculture are common. Smallholder farmers' vulnerability from such income variability is also common. Over the years, a range of risk management strategies have been used to reduce, or to assist farmers to absorb, some of these risks. Since insurance is potentially an important instrument to transfer part of the risk [1, 4, 5, 6, 7]. Agriculture is inherently a risky enterprise because of its dependence on rainfall. To mitigate risks, farmers diversify crops and enterprises, maintain stabilization account or resort to the sale of assets. Crop insurance is a complementary institutional mechanism that aids farmers to cope with risks better [2]. Agriculture is vulnerable to multiple risks, especially in the rain-fed areas. The crop insurance can serve as a useful tool to manage risks in the rain-fed areas [3]. Environment drove climate furthest points fuel provincial neediness and undermines the job of ranchers $[25,11,8,9]$ and their wages change because of climate actuated dangers. Outrageous climate occasions move the whole horticultural economy downwards-wages and resource costs lessening and raise the greatness of pay misfortune past creation misfortune [16]. Farmer's income varies basically due to climate incited dangers, and little and minimal ranchers, who have a helpless 
asset base and who are reliant on characteristic asset blessings, are more powerless to such pay stuns. If not oversaw as expected, chances in agribusiness may hinder financial turn of events [16]. Crop protection diminishes the public authority's need to make calamity instalments; it additionally lessens the danger of loaning and, thus, smoothen credit stream to the farming area. Without protection, farmers may not take advances since they dread losing their guarantee; hence, protection raises credit interest [10]. Yield protection is regularly viewed as an initial phase in building up a sound provincial advancement account foundation, yet reception worldwide has been inconsistent money obliged farmers track down the superior rates excessively high, mindfulness is low, and the protection market is assailed with blemishes [12, 15, 27, 28, 23, 2]. Making crop protection plans adaptable and maintainable presents numerous difficulties [23], one of which is setting an exceptional that farmers discover reasonable [17, 18]. Yield misfortune is resolved utilizing complex re-enactment models at whatever point the climate boundary crosses the pre-indicated limit during the harvest term. Keeping the farmers vows and miseries in consideration a new crop insurance scheme for the benefit of farmers was launched in 2016, with the name 'Pradhan Mantri Fasal Bima Yojana' country wide and so was implemented in the region of Jammu and Kashmir. The present paper will focus on how much a fruit grower is willing pay for availing this insurance to protect the crop from loss.

\section{Methods}

District Shopian of Kashmir valley was chosen for this examination since irrigation is readily available for every crop bases agro-ecosystem, and fruit growing is for the most part is irrigation dependent, failure is viewed as very low that therefore little attention was paid towards any crop protection insurance scheme in the area. But, environmental change has raised the recurrence of climate variations and the danger of horticulture in the area. The data were collected from a sample of 400 apple growers of Shopian district of Kashmir valley during 2021-22 season. The investigation utilizes a defined examining outline, arbitrarily choosing 4 community blocks from Shopian district of Kashmir valley. From each block, two villages were picked for the examination and 50 apple growers were randomly overviewed from chosen villages bringing about an example size of 400 . The unforeseen valuation technique intends to assess, dependent upon the speculative market circumstance, the willingness to pay for change in the arrangement of certain products or administrations [20, 21, 19, 22]. Contingent valuation can be done utilizing a few techniques the most ordinarily utilized are open-ended inquiries, offering game, single-bound or twofold bound dichotomous decision question, and decision tests and the most vigorous are discrete decision strategies, twofold bound or single bound, since they settle on dynamic simple for the respondent. In open-ended inquiries, the respondent is asked straight forwardly to state, dependent upon the speculative market, what they would pay for an item or administration. The open-end question technique is reprimanded on the grounds that it expects respondents to contemplate the reach of utilities and options and show up at an appropriate cost.

Willingness to pay method: For reducing ill-effects of the environment and human health, the new pesticides were assumed to be similar in terms of their pest killing effect to those of currently used pesticides. The algebraic expression for the items of willingness to pay was of the form as:

where,

$$
\text { WTP }=\alpha+\beta_{1} \text { MHh }+\beta_{2} \text { GAg }+\beta_{3} \text { GEd }+\beta_{4} \text { GFEx }+\beta_{5} P I r+\beta_{6} B A h+\beta_{7} \text { KCc }+u_{i}
$$

$\mathrm{WTP}=$ willingness to pay (for insurance scheme); $\alpha=$ intercept; $\mathrm{MHh}=$ Male house hold headed; $\mathrm{GAg}=$ Growers Age; GEd= Growers Education; GFEx= Growers Farm Experience; PIr= Perception of insurable risks; Bah = Bank Account holder; KCch =Kisan Credit card holder.

\section{Results and Discussions}

Table 1 shows the variables that were used for the analysis purpose. On the basis of the available literature, suitable controls are chosen dependent on the hypothetical assumptions. The willingness to pay is assessed by using the contingent valuation method because it is difficult to measure the effect of various factors on the willingness to pay, however, it is feasible to anticipate willingness to pay for every respondent by utilizing the coefficients of greatest probability assessment. The determinants of the ability to pay for protection were investigated utilizing willingness to pay as reliant variable with a bunch of illustrative factors in a straightforward direct relapse structure. Table 1 shows that out of 7 variables, two were measured in years and for other variable a dummy value was assigned for their measurement.

The basic socio-economic characteristics of the respondents obtained from the field survey were averaged to get a reasonable picture for analysis. The average age of the fruit growers in the sampled area was recorded 39.11, the landholding size of the fruit growers on an average was recorded 9.21 kanals as majority of the farmers in Kashmir valley fall under the category of marginal famer's category. Average farming experience of a fruit grower was recorded to be 32.13 years. Majority of the fruit growers in the area fall in the category of educated group by the years of schooling are very less (Middle education). Similarly, 53 per cent of respondents were having access to kisan credit card and 80 per cent possess a bank account in the commercial banks. Likewise, 61 per cent of fruit growers were found aware about 
the prevalence of insurable risks and 59 per cent of the fruit growers have experienced such kind of risks in fruit growing in the respective field of the sampled area and 42 per cent of the fruit growers have perceived climate change with either higher rains/lesser rains or event untimely snow, rains or hailstones (Table 2).

Table 1. Explanation of the variables (control) taken from the respondents of the study area

\begin{tabular}{|c|c|c|}
\hline Variable/factor & $\begin{array}{l}\text { Unit of measure- } \\
\text { ment }\end{array}$ & Description for the variable taken \\
\hline Household with male heads & Dummy & Equal to 1 if the household is male-headed, or otherwise 0 \\
\hline Age of the fruit grower & Years & Age of the household head \\
\hline Education of the fruit grower & Dummy & Equal to 1 if the household is educated, or otherwise 0 \\
\hline Fruit growers experience & Years & Farming experience in years \\
\hline $\begin{array}{l}\text { Fruit growers perception of insurable } \\
\text { risks }\end{array}$ & Dummy & $\begin{array}{c}\text { Equal to } 1 \text { if the household head perceives insurable risks in } \\
\text { farming, or otherwise } 0\end{array}$ \\
\hline Possession of bank account & Dummy & Equal to 1 if he has a bank account, or otherwise 0 \\
\hline Possession of Kissan Credit Card & Dummy & Equal to 1 if he has a credit card, or otherwise 0 \\
\hline
\end{tabular}

Table 2. Averages of the characteristics of the respondents in the sampled area

\begin{tabular}{|c|c|c|}
\hline Parameters/ Factors & Measuring Unit & Average value \\
\hline Age of the fruit grower & Years & 39.11 \\
\hline Land Holding size of fruit growers & Kanals & 9.21 \\
\hline Fruit growers experience & Years & 32.13 \\
\hline Education of the fruit grower & Dummy $=1$ if household head is illiterate, or 0 otherwise & 0.56 \\
\hline Possession of Kissan Credit Card & $\begin{array}{c}\text { Dummy }=1 \text { if anyone in the household has a credit card, or } \\
0 \text { otherwise }\end{array}$ & 0.47 \\
\hline Possession of bank account & $\begin{array}{c}\text { Dummy }=1 \text { if anyone in the household has a bank account, } \\
\text { or } 0 \text { otherwise }\end{array}$ & 0.80 \\
\hline $\begin{array}{l}\text { Fruit growers perception of insurable } \\
\text { risks }\end{array}$ & $\begin{array}{c}\text { Dummy = } 1 \text { if the household head perceives insurable } \\
\text { risks in farming, or } 0 \text { otherwise }\end{array}$ & 0.61 \\
\hline Growers experienced risks & $\begin{array}{c}\text { Dummy = } 1 \text { if he has experienced risks in farming in past } \\
\text { three years, or } 0 \text { otherwise }\end{array}$ & 0.59 \\
\hline Uneven weather perceived & $\begin{aligned} \text { Dummy }= & 1 \text { if actual rainfall is deficit by more or less than } \\
& 15 \text { per cent of normal for the district }\end{aligned}$ & 0.42 \\
\hline
\end{tabular}

To improve the accuracy of estimation we use control variables related to social position, education, risk experience in apple growing, and banking literacy; maximum likelihood estimation method was used to estimate the willingness to pay of respondents regarding these parameters. The coefficients of these control variables (Table 3) are positive and statistically significant, but the magnitude of influence cannot be inferred from the coefficient. Household landholdings have a positive coefficient, in line with the expectation. Aged farmers were reluctant to participate in insurance, as indicated by the negative coefficient for the 'age' variable; the negative relationship between age and demand for crop insurance is well documented $[1,18]$. The willingness to pay for weather-indexed insurance was estimated at Rs. 309/per kanal, with a confidence interval of Rs. 317.41/- per kanal to Rs. 396/- per kanal in the apple growing belt of the Shopian district of Kashmir valley.

Table 4 presents the coefficients of various parameters/factors undertaken for the examination for willing to pay. From the table, it was seen that family landholding size have a positive relationship with the willing to pay for insurance, which means that the apple growers having more land are more inclined towards protection and adapting the danger for crop misfortune (Smith and Watts, 2009) [16, 3, 1, 18]. In like manner, education of the respondent, and ownership of financial services were likewise discovered to be positive and it additionally demonstrates that high qualified individuals know the significance of protection are prepared to pay more for covering the danger of crop in the sampled region and same is the situation with individuals having account in the bank. Financial literacy of the respondent in the sampled region likewise altogether influences interest for crop protection. Which means accordingly that to bring support up in apple crop protection plans, further develop apple producers' financial literacy [13, 3, 24]. Also, the coefficient for 
'experienced risk' is positive, showing that apple producer who had as of late endured crop misfortune are more able to pay than the individuals who had not [14].

Table 3. Estimated willingness to pay for apple crop in the sampled area

\begin{tabular}{|c|c|c|}
\hline Variable/factors & Coefficient & P-value \\
\hline Household with male heads & 233.18 & 0.54 \\
\hline Age of the fruit grower & -28.34 & 0.00 \\
\hline Education of the fruit grower & 77.46 & 0.57 \\
\hline Fruit growers experience & 24.21 & 0.00 \\
\hline Fruit growers perception of insurable risks & 30.44 & 0.82 \\
\hline Growers experienced risks & 35.99 & 0.75 \\
\hline Possession of bank account & 178.68 & 0.29 \\
\hline Possession of Kissan Credit Card & 18.24 & 0.94 \\
\hline Uneven weather & -27.14 & 0.48 \\
\hline Constant & -398.22 & 0.42 \\
\hline \multicolumn{3}{|l|}{ Sigma } \\
\hline Intercept & 582.10 & 0.00 \\
\hline Willingness to pay & 317.41 & 0.00 \\
\hline Coefficient & Std. Err & [95\% confidence interval] \\
\hline Willingness to pay & 46.68 & 317.42 \\
\hline
\end{tabular}

Note: Author's estimates based on field survey

Table 4. Coefficients of willingness to pay of respondents in the sampled area

\begin{tabular}{ccc}
\hline Willingness to pay & Coefficient & P value \\
\hline Age of the fruit grower & -28.34 & 0.00 \\
Education of the fruit grower & 77.46 & 0.00 \\
Fruit growers experience & 24.21 & 0.00 \\
Possession of bank account & 178.68 & 0.00 \\
Possession of Kissan Credit Card & 18.24 & 0.94 \\
Uneven weather & -27.14 & 0.48 \\
\hline
\end{tabular}

\section{Conclusion}

The horticultural area is vulnerable to numerous dangers, particularly because of changing climatic conditions. The landholding size is less in the sampled region, and the organic apple growers cannot adapt up to the various dangers, consequently the list based protection can fill in as a danger the executives system. The organic product cultivator's eagerness to take part in the food and money crops protection plans are affected by various elements, particularly the social capital. With the presentation of the file based protection, the ranchers' decision for the money yields should change as the money crops which used to be productive, yet hazardous, will currently be more secure. By lessening the level of danger in rural creation, natural product cultivators will resort less to hazard. One ought to thusly anticipate expanded specialization and high benefits, as farmer's centre around augmenting the yield of the protected harvest, as opposed to on enhancing the climate hazard through the trimming framework. The current paper exhibits that apple growers are willing to pay Rs. 305/- per kanal of land. The examination finds that apple growers willingness to pay is insistently influenced by their money related capability, wealth, and experience of gather adversity.

\section{Acknowledgements}

This paper is outcome of research studies carried out by University Grants Commission, New-Delhi sponsored Rajiv Gandhi Chair in Contemporary Studies on Livelihood and Food Security. The authors are grateful to University Grants Commission and Vice-Chancellor of Sher-e-Kashmir University of Agricultural Sciences and Technology of Kashmir, Shalimar Srinagar for their financial and logical support. We are also highly grateful to the respondents for their well response in conducting the survey and collection of data. 


\section{Conflict of interest}

The authors declare that they have no conflict of interests.

\section{References}

[1] Abebe, H. T. and A. Bogale. (2014). Willingness to pay for rainfall-based insurance by smallholder farmers in Central Rift Valley of Ethiopia: The Case of Dugda and Mieso Woredas. Asia Pacific Journal of Energy and Environment, 1(2): $121-57$. doi.org/10.15590/apjee/ 2014/v1i2/53750.

[2] Aditya, K. S., M. Khan, and A. Kishore. (2018). Adoption of crop insurance and impact: insights from India. Agricultural Economics Research Review, 31(2): 163-74. doi.org/10.5958/0974-0279.2018.00034.4.

[3] Ali, A. (2013). Farmers’ Willingness to Pay for Index Based Crop Insurance in Pakistan: A Case Study on Food and Cash Crops of Rain-fed Areas. Agricultural Economics Research Review, 26(2): 241-48. doi.org/10.22004/ ag.econ.162145.

[4] Bardsley, Peter, Abey, Arun, and Davenport, Scott. (1984). The economics of insuring crops against drought. Australian Journal of Agricultural Economics, 28(1): 1-14.

[5] Barnett, B. J., Skees, J. R., and Hourigan, J. D. (1990). Examining Participation in Federal Crop Insurance. Staff Paper No. 275, Department of Agricultural Economics, University of Kentucky.

[6] Bastian, C. (1999). Crop Insurance as a Tool, Risk and Resilience in Agriculture, University of Wyoming, Cooperative Extension Service, pp. 1-7, available at: www.uwagec.org/rnrinag/RnR\%20Section\%202/Crop\%20Insurance\%20as\%20a\%20 Tool.pdf.

[7] Bielza Diaz-Caneja, M., Conte, C. G., Gallego Pinilla, F. J., Stroblmair, J., Catenaro, R., and Dittmann, C. (2009). Risk Management and Agricultural insurance Schemes in Europe, European Commission, Joint Research Centre, Institute for Protection and Security of Citizen, Luxembourg.

[8] Birthal, P. S. and J. Hazrana. (2019). Crop diversification and resilience of agriculture to climatic shocks: Evidence from India. Agricultural Systems, 173: 345-54. doi.org/ 10.1016/j.agsy.2019.03.005.

[9] Birthal, P. S., J. Hazrana, and D. S. Negi. (2019). A multilevel analysis of drought risk in Indian agriculture: implications for managing risk at different geographical levels. Climatic Change, 157(3-4): 499-513. doi.org/ 10.1007/s10584-019-02573-9.

[10] Carter, M. R., F. Galarza, and S. Boucher. (2007). Underwriting area-based yield insurance to crowd-in credit supply and demand. Savings and Development, 31(3): 335-60. EconPapers.repec.org/RePEc:pra:mprapa:24326.

[11] Enjolras, G., Capitation, F., and Adinolfi, F. (2012). The demand for crop insurance: Combined approaches for France and Italy, Agricultural Economics Review, Vol. 13, No. 1, pp. 5-22.

[12] Gardner, B. L. and Kramer, R. A. (1986). Experience with crop insurance programs in the United States. In: Crop Insurance for Agricultural Development: Issues and Experience, John Hopkins University Press, Baltimore.

[13] Gine, X., L. Menand, R. Townsend, and J. Vickery. (2010). Micro insurance: a case study of the Indian rainfall index insurance market (report No. 5459). The World Bank, Washington D.C., USA.EconPapers.repec.org/ RePEc: wbk:wbrwps:5459.

[14] Gollier, C. (2003). To insure or not to insure? The Geneva Papers on Risk and Insurance Theory, 28(1): 5-24. link.springer.com/content/pdf/10.1023/ A: 1022112430242.pdf.

[15] Gustafsson-Wright, E., Asfaw, A., and van der Gaag, J. (2009). Willingness to pay for health insurance: An analysis of the potential market for new low-cost health insurance products in Namibia. Social Science and Medicine, 69(9): 1351-1359.

[16] Hazell, P. B. R., J. Anderson, N. Balzer, C. A. Hastrup, U. Hess, and F. Rispoli. (2010). The potential for scale and sustainability in weather index insurance for agriculture and rural livelihoods. World Food Programme (WFP), Rome, Italy. https://documents.wfp.org/stellent/groups/ public/documents/newsroom/wfp281391.pdf?_ga =2. 143556598.2594753 35. 1594876827 -948204335.1594876827.

[17] Just, R., Calvin, E. L., and Quiggin, J. (1999). Adverse selection in crop insurance: Actuarial and Asymmetric Information Incentives. American Journal of Agricultural Economics, 81(4): 834-849.

[18] Liesivaara, P. and S. Myyra. (2014). Willingness to pay for agricultural crop insurance in the northern EU. Agricultural Finance Review, 74(4): 539-54. doi.org/10.1108/afr-06-2014-0018.

[19] López-Feldman, A. (2013). Introduction to contingent valuation using Stata. In Mexican Stata Users Group Meetings 2013 (No. 12). Stata Users Group. https:// mpra.ub.uni-muenchen.de/41018/2/MPRA_paper_41018.pdf.

[20] Musser, W. N. (1998). Risk management overview. Paper presented at Mid-Atlantic Risk Management Regional Conference, Williamsburg, VA, 6-7 August.

[21] Patrick, G. F. (1998). Managing Risk in Agriculture. North Central Region Extension Publication, No. 406.

[22] Qureshi, N. W., M. Krishnan, C. Sundaramoorthy, A. K. Vasisht, S. Baba, N. R. Kumar, and R. Sharma. (2013). Truncated growth and compromised sustainability: The case of lake fisheries in Kashmir. Agricultural Economics Research Review, 26(Conference Number): 57-66. http://purl.umn.edu/158508. 
[23] Santeramo, F. G., B. K. Goodwin, F. Adinolfi, and F. Capitanio. (2016). Farmer Participation, Entry and Exit Decisions in the Italian Crop Insurance Programme. Journal of Agricultural Economics, 67(3): 639-657. https://doi.org/ 10.1111/1477-9552.12155.

[24] Singh, R. (2013). Agricultural Livelihoods and Crop Insurance in India. Working paper, Deutsche Geselschaft fiir internationale Zusammenarbeit (GIZ) GmbH: New Delhi. http://www.ruralfinanceandinvestment.org/sites/default/ files/Agricultural\%20Livelihoods\%20and\%20Crop\%20Insurance\%20in\%20India.pdf.

[25] Smith, V. H. and Glauber, J. W. (2012). Agricultural Insurance in Developed Countries: Where Have We Been and Where Are We Going? Applied Economic Perspectives and Policy, vol. 34, no. 3, pp. 363-390.

[26] Smith, V. H. and Watts, M. (2009). Index Based Agricultural Insurance in Developing 573 EP 2014 (61) 3 (561-573) Crop Insurance-Risks and Models of Insurance Countries: Feasibility, Scalability and Sustainability, Monograph published electronically by the Bill and Melinda Gates Foundation, November 2009, available at: www.yumpu.com/en/document/view/16834278/index-based-agriculturalinsurance-in-developing-countries-.

[27] Hardaker, J. B., Huirne, R. B. M., and Anderson, J. R. (1997). Coping with Risk in Agriculture. CAB International, New York.

[28] O’donoghue, E. J., M. J. Roberts, and N. Key. (2009). Did the federal crop insurance reform act alter farm enterprise diversification? Journal of Agricultural Economics, 60(1): 80-104. doi.org/10.1111/j.1477-9552. 2008.00166. 